\title{
Effect of Irrigation Using Diluted Winery Wastewater on the Chemical Status of a Sandy Alluvial Soil, With Particular Reference to Potassium and Sodium
}

C.L. Howell ${ }^{1 *}$, P.A. Myburgh ${ }^{1}$, E.L. Lategan ${ }^{1}$, J.E. Hoffman ${ }^{2}$

(1) The Fruit, Vine and Wine Institute, Agricultural Research Council (ARC) Infruitec-Nietvoorbij, Private Bag X5026, Stellenbosch 7599, South Africa

(2) Department of Soil Science, Stellenbosch University, Private Bag X1, Matieland 7602

Submitted for publication: January 2018

Accepted for publication: April 2018

Key words: Cabernet Sauvignon, chemical oxygen demand, grapevines

\begin{abstract}
The re-use of winery wastewater for irrigation was investigated in a field trial with micro-sprinklerirrigated Cabernet Sauvignon/99 Richter in the Breede River Valley region of South Africa. Irrigation with winery wastewater diluted with river water to 100, 250, 500, $1000,1500,2000,2500$ and $3000 \mathrm{mg} / \mathrm{L}$ chemical oxygen demand (COD) was compared to irrigation with river water. No trends were found in soil $\mathrm{pH}_{(\mathrm{KCl})}$ and electrical conductivity of the saturated soil extract $\left(\mathrm{EC}_{\mathrm{e}}\right)$ that were related to the different levels of dilution. However, $\mathrm{EC}_{\mathrm{e}}$ was considerably higher after the application of diluted winery wastewater irrigations compared to $\mathrm{EC}_{\mathrm{e}}$ at bud break. This suggests an accumulation of salts from the diluted winery wastewater. Under the prevailing conditions, soil $\mathrm{K}^{+}$and $\mathrm{Na}^{+}$increased with a decrease in the dilution of the winery wastewater. Increases in $\mathrm{K}^{+}$could have a negative impact on wine colour stability should potassium be taken up by the grapevine in sufficient quantities, particularly if soil $\mathrm{K}^{+}$accumulates to such an extent that it is luxuriously absorbed by grapevines. There were no consistent trends with regard to soil organic $C$, which indicates that there was too little organic material in the wastewater to have had a positive effect on soil fertility. Furthermore, organic material in the wastewater probably oxidised when the soil was aerated between irrigations. Although irrigation with diluted winery wastewater had almost no other effects, element accumulation, particularly with respect to $\mathrm{K}^{+}$and $\mathrm{Na}^{+}$, might be more prominent in heavier soils or in regions with low winter rainfall.
\end{abstract}

\section{INTRODUCTION}

During the grape harvest period, wineries produce large volumes of low-quality wastewater that can contain high levels of $\mathrm{K}^{+}$and $\mathrm{Na}^{+}$. The chemical status of this water is generally worse than the legislated limits for irrigation with wastewater (Department of Water Affairs, 2013). Information on actual volumes of wastewater generated by wineries is extremely limited. The management of winery wastewater by re-using it for crop irrigation was recently reviewed by Howell and Myburgh (2018). A brief summary is as follows: Medium to large wineries generate more than $15000 \mathrm{~m}^{3}$ of wastewater annually, whereas small wineries generate less than $15000 \mathrm{~m}^{3}$ annually (Van Schoor, 2005 and references therein). It is estimated that $c .3$ to $5 \mathrm{~m}^{3}$ of winery wastewater, with a high organic load and variable salinity and nutrient levels, is produced per tonne of grapes crushed (Mosse et al.,
2011). On the other hand, limited irrigation water supplies could be further restricted in future allocations of irrigation water (Van Zyl \& Weber, 1981; Petrie et al., 2004). If winery wastewater could be re-used to irrigate vineyards, with no detrimental impacts on soil chemical status, it could be a viable alternative to using water abstracted from natural resources.

Currently, the Department of Water and Sanitation is drafting new General Authorisations for wineries. Depending on the permitted water quality limits and volumes stipulated by the new authorisations, diluting winery wastewater with irrigation water may well become a more viable practice in the future. Re-using winery wastewater in this way will be beneficial, particularly where there are water shortages. In such situations, re-using winery wastewater will have a

*Corresponding author: E-mail address: HowellC@arc.agric.za

Acknowledgments: The project was initiated and funded by the Water Research Commission. The project was co-funded by Winetech, THRIP TP 1208066038 and the Agricultural Research Council. We thank Goudini Winery, for permission to work at their winery and in their vineyard, as well as for the grapes used for samples and winemaking. Thanks also to Messrs Willie and Daniël Botha, for managing the vineyard and for general assistance. The staff of the Soil and Water Science Programme at the ARC Infruitec-Nietvoorbij are thanked for their technical support. Any opinions, findings and conclusions or recommendations expressed in any publication generated through THRIP-supported research are those of the author(s), and therefore the NRF/THRIP will not accept any liability in that regard 
positive impact on grape yields if additional irrigation can be applied. Water saving and higher yields will also contribute to the sustainability and economic viability of wine production. Presently, there is increasing pressure on producers to use water in a more environmentally friendly way. If winery wastewater could be re-used sustainably, it could also have other benefits, such as a reduction in the energy required for wastewater treatment and an increase in the availability of nutrients. Plant nutrients in the wastewater, such as $\mathrm{K}^{+}$, $\mathrm{Ca}^{2+}$ and $\mathrm{Mg}^{2+}$, could reduce fertiliser requirements, thereby reducing fertilisation costs. In addition, land application of wastewaters can increase soluble and exchangeable forms of $\mathrm{K}^{+}$more rapidly than with conventional inorganic fertilisers, and most of the $\mathrm{K}^{+}$is available immediately (Arienzo et al., 2009). Although it appears that the $\mathrm{N}$ load in diluted winery wastewater would be inadequate to supply the grapevine's $\mathrm{N}$ requirement, $\mathrm{P}$ and $\mathrm{K}^{+}$applied via diluted winery wastewater should be adequate for a grape yield of $c .10 \mathrm{t} / \mathrm{ha}$ (Howell et al., 2015).

Although there is extensive literature on the effect of irrigation with wastewaters of various origins on soil chemical properties (Smiles \& Smith, 2004; Hulugalle et al., 2006; Walker \& Lin, 2008; Duan et al., 2010; Rana et al., 2010; Laurenson, 2010; Lado et al., 2011; Moraetis et al., 2011; Blum et al., 2012; Barbera et al., 2013; Di Bene et al., 2013; Netzer et al., 2014), there is no information regarding the re-use of winery wastewater diluted to pre-determined levels of chemical oxygen demand (COD) for any crop. The management of winery wastewater by re-using it for crop irrigation was recently reviewed by Howell and Myburgh (2018). A brief summary of the response of soil chemical properties to winery wastewater irrigation is as follows: In general, there was an increase in soil $\mathrm{K}^{+}$and $\mathrm{Na}^{+}$(Kumar et al., 2006, 2009; Mulidzi et al., 2009; Quale et al., 2010; Mosse et al., 2012; Kumar et al., 2014) where winery wastewater was used for irrigation. In a field study in which grapevines were irrigated with simulated winery wastewater, soil $\mathrm{Na}^{+}$ levels also increased (Mosse et al., 2013). In a laboratory study, irrigation with winery wastewater increased soil $\mathrm{Na}^{+}$ and $\mathrm{K}^{+}$in a loamy sand, a loam and a clayey soil (Kumar et al., 2006). In another laboratory study, using winery wastewater for irrigation also increased the soil $\mathrm{K}^{+}$of a deep sand, clay loam and a hard setting sandy loam (Laurenson, 2010).

Irrigation with wastewaters containing high levels of $\mathrm{K}^{+}$, such as winery wastewater, could be beneficial to overall soil fertility, although long-term application could have negative effects on soil chemical and physical properties (Smiles \& Smith, 2004; Kumar et al., 2009; Laurenson et al., 2011; Mosse et al., 2011). The effects of high $\mathrm{K}^{+}$concentrations on soil properties have not been researched extensively and are still unclear (Kumar et al., 2009; Mosse et al., 2011; Laurenson et al., 2012). However, the accumulation of monovalent ions in the soil can deteriorate soil structure and hydraulic conductivity, thereby reducing soil productivity (Smiles \& Smith, 2004; Kumar et al., 2006; Laurenson et al., 2011). In addition to $\mathrm{K}^{+}$and $\mathrm{Na}^{+}$, winery wastewater can contain $\mathrm{Ca}^{2+}$ and $\mathrm{Mg}^{2+}$ (Mosse et al., 2011). Neither of the latter mentioned ions are harmful to soil structure and can ameliorate the impacts of $\mathrm{Na}^{+}$via their role in reducing the SAR. However, a matter of potential concern is $\mathrm{Na}^{+}$ and $\mathrm{Mg}^{2+}$ accumulation in surface soils and a subsequent loss of $\mathrm{Ca}^{2+}$ (Laurenson, 2010). A literature search revealed that the effect of irrigation with winery wastewater on soil $\mathrm{P}$ is not well documented. With respect to P, Mulidzi et al. (2009) reported that land application of undiluted winery wastewater increased soil $\mathrm{P}$, but that the $\mathrm{P}$ in the different soil horizons fluctuated throughout the season.

The objective of this study was to determine the effect of irrigation with winery wastewater diluted to eight different levels of COD on the soil chemical status of a sandy, alluvial vineyard soil in order to determine a possible threshold concentration for sustainable use.

\section{MATERIALS AND METHODS \\ Experimental design and layout}

The field trial was carried out in a micro-sprinkler-irrigated Cabernet Sauvignon/99 Richter vineyard in the Breede River Valley region of South Africa. The locality is at $33^{\circ}$ $41^{\prime}$ latitude and has a Mediterranean climate. Based on the growing degree days from September until March (Winkler, 1962), the specific locality is in a class V climatic region for wine quality potential (Le Roux, 1974). According to the Köppen-Geiger climate classification, the Rawsonville climate is classified as a Csa, which means that the region has a temperate climate with hot, dry summers (Peel et al., 2007). The vineyard is located on an alluvial flood plain of the Du Toit's Kloof mountains. The sandy soil, i.e. less than $5 \%$ clay, belongs to the Longlands form (Soil Classification Working Group, 1991). The soil was deep-delved to 1.0 $\mathrm{m}$ before planting. Grapevines were planted at $2.4 \mathrm{~m} \times$ $1.2 \mathrm{~m}$ and trained onto a four-strand lengthened Perold trellis (Booysen et al., 1992). Vertical shoot positioning was carried out to prevent shoots from sprawling into the work rows. Irrigation using winery wastewater diluted to 100,250 , 500, 1 000, 1 500, 2 000, 2500 and $3000 \mathrm{mg} / \mathrm{L}$ COD was compared to irrigation using river water abstracted from the Holsloot River. All treatments were replicated three times in a randomised block design. Experiment plots comprised two rows of six grapevines each, with two buffer grapevines at each end and a buffer row on each side. Each experiment plot covered $104 \mathrm{~m}^{2}$. Treatments were applied from 2009/2010 until 2012/2013. In the 2009/2010 season, it was only possible to apply the diluted wastewater treatments after harvest due to completion of the infrastructure. Details of the irrigation infrastructure and dilution procedures (Myburgh et al., 2015), as well as an assessment of the water quality and nutrient load of the diluted winery wastewater, were reported previously (Howell et al., 2015).

The diluted wastewater treatments were applied from mid-February, when high volumes of wastewater became available from vintage processes. Grapevines were irrigated at c. 50\% plant available water (PAW) depletion. Irrigation had to be applied every two weeks to maintain this PAW depletion level. Irrigations were stopped either in mid-April or at the beginning of May each year, when the wastewater volumes decreased and the first winter rains fell. Water meters were used to monitor the irrigation volumes applied to each treatment. Grapevines in all treatments received the same volume of water per irrigation. In addition to standard 
viticultural practices, measures were taken to prevent erinose mite infestation in the vineyard. This consisted of a lime sulphur spray prior to bud break, as well as three additional sprays of MicroThiol ${ }^{\mathrm{TM}}$.

After an evaluation of the soil mineral status at bud break, i.e. mid-September, $\mathrm{K}^{+}$fertilisation was applied in all three seasons at a rate of $30 \mathrm{~kg} \mathrm{~K}^{+}$per ha. In 2010/2011, $\mathrm{KCl}$ was applied to all treatments in the middle of November. However, in the $2011 / 2012$ season, $30 \mathrm{~kg} \mathrm{~K}^{+}$per ha was only applied to $\mathrm{T} 1$ to $\mathrm{T} 6$ in the middle of December. The soil $\mathrm{K}^{+}$content of T7, T8 and T9 was deemed sufficient for the grapevines. In the $2012 / 2013$ season, $\mathrm{K}^{+}$fertilisation was applied to all plots in December. An interception crop of Pennisetum glaucum (pearl millet) was cultivated in the work rows in summer to intercept salts applied via the diluted winery wastewater. It produced $10.4 \pm 0.8,6.0 \pm 1.0$ and $6.4 \pm 0.9 \mathrm{t} /$ ha dry matter for the 2010/2011, 2011/2012 and 2012/2013 seasons respectively (Fourie et al., 2015). A winter cover crop of Avena sativa L. cv. Pallinup (oats) was cultivated in the 2009/2010, 2010/2011, 2011/2012 and 2012/2013 seasons and produced $5.4 \pm 0.3,4.7 \pm 1.0$, $6.7 \pm 1.2$ and $7.5 \pm 1.1 \mathrm{t} /$ ha dry matter respectively (Fourie et al., 2015). The foliage of the interception crop was slashed and removed in the beginning of March and third week of April, and that of the cover crop at the end of August.

\section{Soil chemical status}

Soil samples were collected using an auger in August 2009 before the trial commenced to determine the baseline chemical status before treatments were applied. Samples were taken over $30 \mathrm{~cm}$ increments to a depth of $1.8 \mathrm{~m}$. After the first season of wastewater application, in May 2010, soil samples were collected over the same depth increments in the work rows of all experiment plots. Soil from each of the three replications of each treatment was pooled for analysis. Soil samples were also collected at bud break in October 2010, September 2011 and September 2012 in the work rows of all plots. Soil from the three replications of each treatment was also pooled for analysis. In April 2011, soil samples were collected from each of the three replications of the river water control (T1), as well as from where winery wastewater was diluted to 250 (T3), 1000 (T5), 2000 (T7) and $3000 \mathrm{mg} / \mathrm{L}$ COD (T9). The samples were collected $c$. one week after the end of the wastewater application. In order to determine possible differences in the soil chemical properties within the vineyard due the water distribution pattern of the irrigation system, samples were taken in the work row and in the grapevine row. In contrast to soil samples taken in early May 2010, no rain occurred in the period preceding the collection of these samples. The same procedure was followed for samples collected after the wastewater application had stopped in May 2012 and 2013. At the end of the trial in September 2013, soil samples were collected in the work rows of all the experiment plots over $30 \mathrm{~cm}$ increments to a depth of $3.0 \mathrm{~m}$ using an extended soil auger.

All samples were analysed by a commercial laboratory (Bemlab, Strand). Soil $\mathrm{pH}_{(\mathrm{KCl})}$ was measured in $1 \mathrm{M} \mathrm{KCl}$. Electrical conductivity of the saturated extract $\left(\mathrm{EC}_{\mathrm{e}}\right)$ was determined in a US Bureau of Standards cup. To determine the exchangeable acidity of the soil, $\mathrm{Al}^{3+}$ and $\mathrm{H}^{+}$were extracted with $1 \mathrm{~N}$ of $\mathrm{KCl}$ and titrated to the end point with $\mathrm{NaOH}$ $(0.01 \mathrm{M})$. The acidity was expressed as an equivalent of $\mathrm{H}^{+}$ in $\mathrm{cmol}^{(+)} / \mathrm{dm}^{3}$ soil (The Non-Affiliated Soil Analyses Work Committee, 1990). The Bray No. 2 method, i.e. extraction with $0.03 \mathrm{M} \mathrm{NH}_{4} \mathrm{~F}$ in $0.01 \mathrm{M} \mathrm{HCl}$, was used to determine $\mathrm{P}$ and $\mathrm{K}^{+}$. The $\mathrm{P}$ and $\mathrm{K}^{+}$concentrations in the extract were determined by inductively coupled plasma optical emission spectrometry (ICP-OES) using a spectrometer (PerkinElmer Optima 7300 DV, Waltham, Massachusetts). The $\mathrm{Ca}^{2+}, \mathrm{Mg}^{2+}$, $\mathrm{K}^{+}$and $\mathrm{Na}^{+}$were only extracted with $1 \mathrm{M}$ of ammonium acetate at $\mathrm{pH} \mathrm{7,} \mathrm{and} \mathrm{their} \mathrm{concentrations} \mathrm{in} \mathrm{the} \mathrm{extract} \mathrm{were}$ determined by ICP-OES using a spectrometer (PerkinElmer Optima 7300 DV). Since the amounts of soluble cations were not determined, the amount of exchangeable cations, which is the extractable minus the soluble amounts (Richards, 1954), could not be calculated. Therefore, the cation exchange capacity (CEC) could not be calculated. Due to the tedious process of determining the exchangeable cations and $\mathrm{CEC}$, most South African laboratories only determine extractable cations (Conradie, 1994). Therefore, most laboratories calculate the sum of the extractable cations to obtain an estimated CEC, which is also referred to as the S-value. Given the abovementioned, the exchangeable potassium percentage (EPP) and exchangeable sodium percentage (ESP) of the soil could not be calculated. However, the extractable potassium percentage (ExPP) was calculated as follows:

$\operatorname{ExPP}=\left(\mathrm{K}^{+} \div \mathrm{S}\right) \times 100$

where $\mathrm{K}^{+}$is the extractable potassium $\left(\mathrm{cmol}^{(+)} / \mathrm{kg}\right)$ and $\mathrm{S}$ is the S-value $\left(\mathrm{cmol}^{(+)} / \mathrm{kg}\right)$, i.e. the sum of the $\mathrm{Ca}^{2+}, \mathrm{Mg}^{2+}, \mathrm{K}^{+}$ and $\mathrm{Na}^{+}$.

The extractable sodium percentage (ExSP) was calculated as follows:

$\operatorname{ExSP}=\left(\mathrm{Na}^{+} \div \mathrm{S}\right) \times 100$

where $\mathrm{Na}^{+}$is the extractable sodium $\left(\mathrm{cmol}^{(+)} / \mathrm{kg}\right)$ and $\mathrm{S}$ is the $\mathrm{S}$-value $\left(\mathrm{cmol}^{(+)} / \mathrm{kg}\right)$, i.e. the sum of the $\mathrm{Ca}^{2+}, \mathrm{Mg}^{2+}, \mathrm{K}^{+}$and $\mathrm{Na}^{+}$.

The designation ExPP is used so as not to confuse extractable potassium percentage, which includes both adsorbed $\mathrm{K}^{+}$and $\mathrm{K}^{+}$in solution, with EPP. Likewise, the designation ExSP is used so as not to confuse extractable sodium percentage, which includes both adsorbed $\mathrm{Na}^{+}$and $\mathrm{Na}^{+}$in solution, with ESP. Total organic $\mathrm{C}$ contents were determined using the method described by Walkley and Black (1934).

\section{Statistical analysis}

Linearregressionswerecalculatedusing STATSGRAPHICS $®$ version XV (StatPoint Technologies, Warrenton, Virginia, USA).

\section{RESULTS AND DISCUSSION \\ Soil $\mathbf{p H}, \mathrm{H}^{+}$and $\mathrm{EC}_{\mathrm{e}}$}

After wastewater application, there were no clear trends in soil $\mathrm{pH}_{(\mathrm{KCl})}$ that could be related to the different dilution levels of winery wastewater compared to the river water 
control (data not shown). Similarly, there was no change in soil $\mathrm{pH}$ where winery wastewater was used for the irrigation of soil with a clay content of $50 \%$ to $60 \%$ (Quale et al., 2010). In contrast, soil $\mathrm{pH}_{(\mathrm{H} 2 \mathrm{O})}$ of a silty clay loam soil that received solid and liquid winery waste for 30 years tended to increase compared to soil to which no waste was applied (Mosse et al., 2012). In two case studies where pastures and a vineyard were irrigated with winery wastewater, soil $\mathrm{pH}$ also increased (Kumar et al., 2014). In the latter study, it seemed that irrigation with winery wastewater actually caused a decrease in soil $\mathrm{pH}$ when the results were compared to the results of a historical dataset of soil chemical properties. In a laboratory study in which mains water, municipal wastewater and winery wastewater was used for irrigation of a sand, loamy sand and sandy loam, there was an increase in soil $\mathrm{pH}_{(1: 5)}$ (Laurenson, 2010). However, it should be borne in mind that the $\mathrm{pH}$ of the winery wastewater in that particular study was 8.5. There have also been conflicting reports of either an increase or decrease in soil $\mathrm{pH}$ (Laurenson et al., 2012 and references therein). It was suggested that these changes in soil $\mathrm{pH}$ can be related to the characteristics of the wastewater. If wastewaters contain high concentrations of bicarbonate, application to soils will increase $\mathrm{pH}$, whereas acidic wastewaters could reduce soil $\mathrm{pH}$.

Where winery wastewater was diluted to $3000 \mathrm{mg} / \mathrm{L}$ $\mathrm{COD}$, soil $\mathrm{pH}_{(\mathrm{KCl})}$ increased from May (autumn) to bud break (Fig. 1). Since irrigation using winery wastewater is likely to increase soil $\mathrm{K}^{+}$and $\mathrm{Na}^{+}$, soil $\mathrm{pH}$ will consequently increase via alkaline hydrolyses. This reaction is primarily caused by the hydrolysis of exchangeable cations in the soils, e.g. $\mathrm{K}_{\text {ex }}^{+}$and $\mathrm{Na}^{+}{ }_{\text {ex }}$, or salts, e.g. $\mathrm{CaCO}_{3}, \mathrm{MgCO}_{3}$ and $\mathrm{Na}_{2} \mathrm{CO}_{3}$ (Abrol et al., 1988). Hydrogen ions $\left(\mathrm{H}^{+}\right)$are inactivated by exchange adsorption in the place of exchangeable $\mathrm{K}^{+}$and $\mathrm{Na}^{+}$. These displaced cations do not inactivate the hydroxide anions $\left(\mathrm{OH}^{-}\right)$, which in turn cause soil $\mathrm{pH}$ to increase. The extent to which exchangeable cations hydrolyse depends on their ability to compete with $\mathrm{H}^{+}$for exchange sites. Exchangeable $\mathrm{Ca}^{2+}$ and $\mathrm{Mg}^{2+}$ are more tightly adsorbed to the exchange complex than $\mathrm{K}^{+}$and $\mathrm{Na}^{+}$. Therefore, $\mathrm{K}^{+}$ and $\mathrm{Na}^{+}$are more readily hydrolysed and produce a higher $\mathrm{pH}$ than do exchangeable $\mathrm{Ca}^{2+}$ or $\mathrm{Mg}^{2+}$. The hydrolysis of exchangeable $\mathrm{Ca}^{2+}$ and $\mathrm{Mg}^{2+}$, in fact, is so limited that it results in a soil having only a mildly alkaline reaction. In the present study, excessive soil $\mathrm{K}^{+}$after wastewater application, in conjunction with the relatively high winter rainfall in this region, induced alkaline hydrolysis, thereby increasing soil $\mathrm{pH}_{(\mathrm{KCl})}$ at bud break. This does not rule out the possibility of the dissociation of organic acids. The cations in the diluted wastewater were probably present in the form of organic salts. These salts can produce $\mathrm{OH}^{-}$anions via decarboxylation, which will increase the soil $\mathrm{pH}$ (Rukshana et al., 2011). Organic acids present in the wastewater may also be a source of organic anions via the dissociation of $\mathrm{H}^{+}$, which can increase the soil $\mathrm{pH}$ via decarboxylation. If this happens, the soil might initially contain more $\mathrm{H}^{+}$, but the $\mathrm{pH}$ will increase over time as more $\mathrm{OH}^{-}$is formed (Rukshana et al., 2011).

Baseline values for $\mathrm{pH}_{(\mathrm{KCl})}$ were 5.3 and 4.7 for the 0 to $90 \mathrm{~cm}$ and 90 to $180 \mathrm{~cm}$ soil layers respectively (Tables 1 \& 2). Soil $\mathrm{pH}_{(\mathrm{KCl})}$ levels remained similar to baseline values until the end of the trial in September 2013, when the soil $\mathrm{pH}_{(\mathrm{KCl})}$ in both the 0 to $90 \mathrm{~cm}$ and 90 to $180 \mathrm{~cm}$ layers tended to be lower than the baseline values. In particular, the $\mathrm{pH}_{(\mathrm{KCl})}$ in the 90 to $180 \mathrm{~cm}$ layer tended to be below the norm of 5.0 to 7.5 recommended by Saayman (1981) for optimal grapevine growth. However, under the prevailing conditions, visual observations indicated that there were no adverse effects of low sub-soil $\mathrm{pH}$ on grapevine performance.

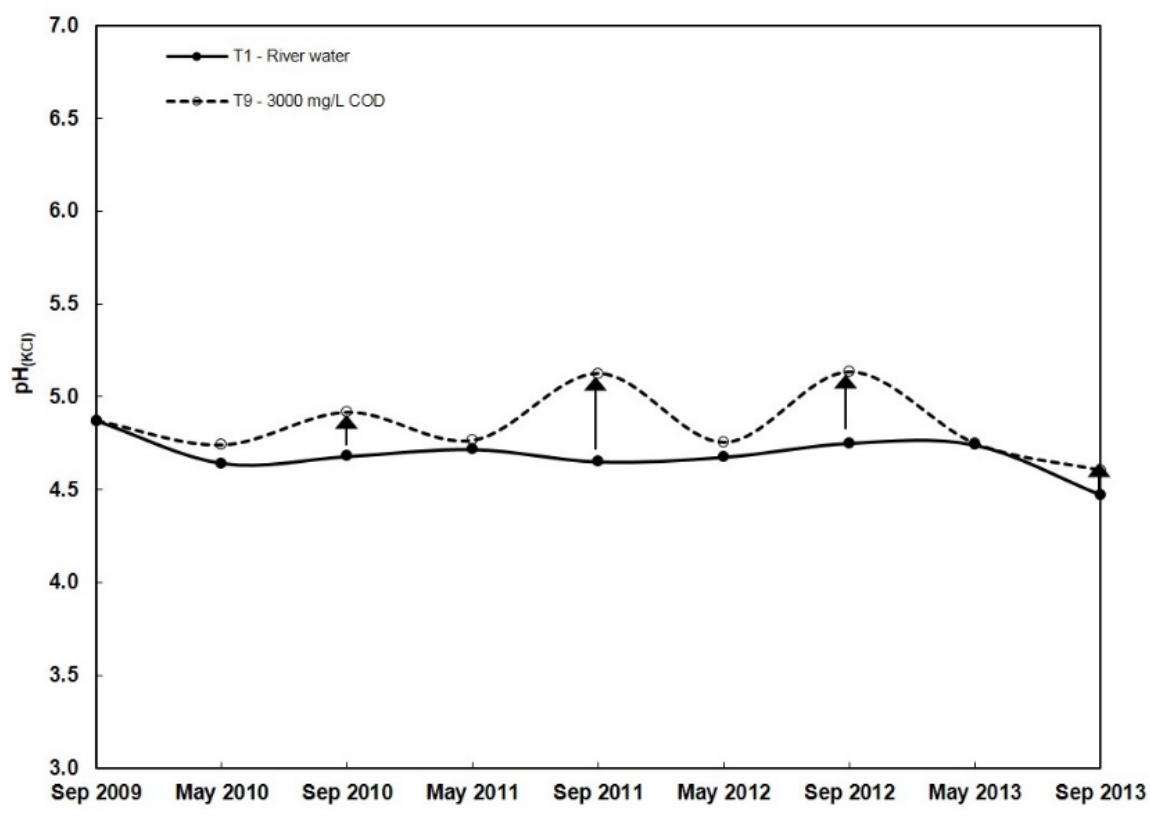

FIGURE 1

Seasonal variation in soil $\mathrm{pH}_{(\mathrm{KCl})}(0$ to $180 \mathrm{~cm}$ depth) for two water qualities in the work rows of a vineyard in a sandy soil near Rawsonville from the beginning to the end of the trial. 


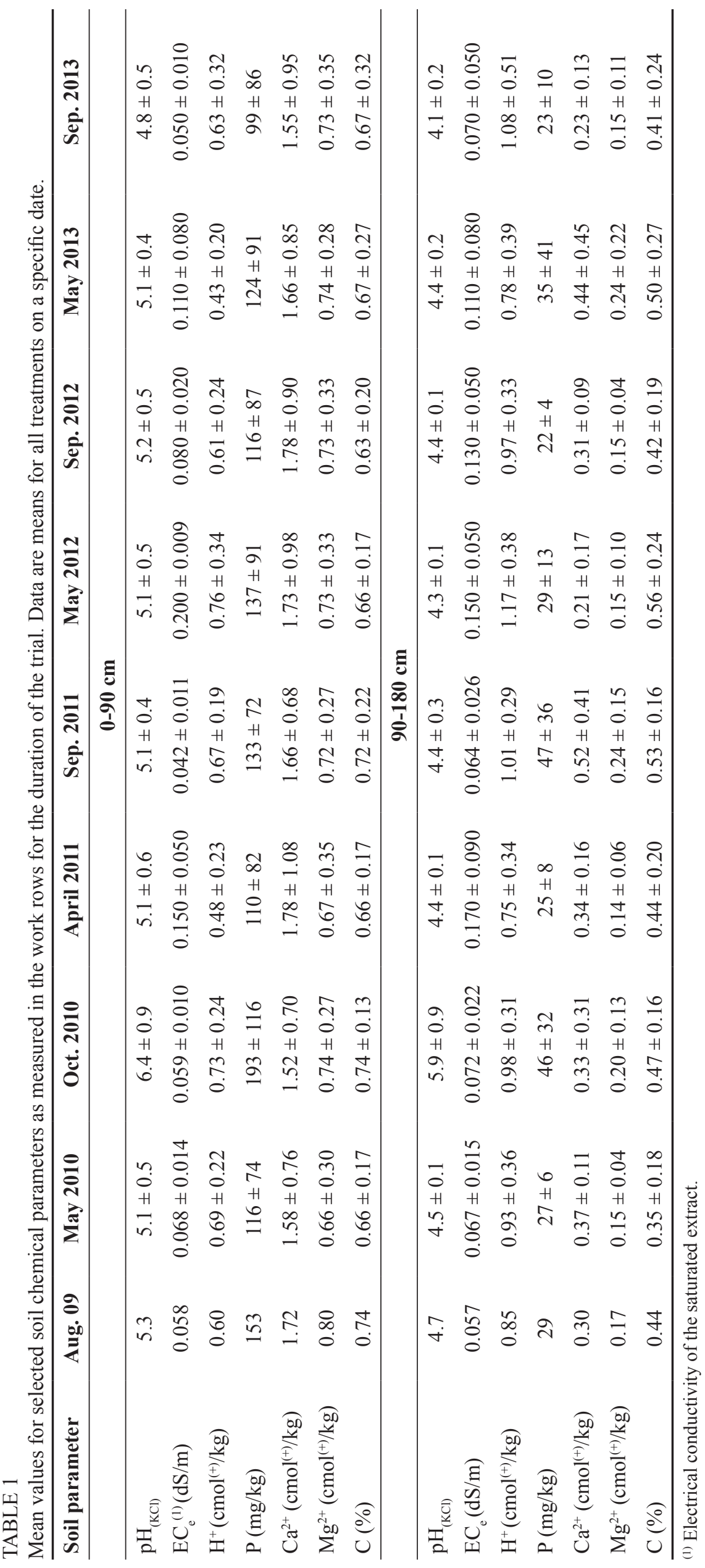


TABLE 2

Mean values of selected soil chemical parameters as measured in the grapevine rows for the duration of the trial. Data are means for all treatments on a specific date.

\begin{tabular}{|c|c|c|c|c|}
\hline Soil parameter & Aug. 09 & April 2011 & May 2012 & May 2013 \\
\hline \multicolumn{5}{|c|}{$0-90 \mathrm{~cm}$} \\
\hline $\mathrm{pH}_{(\mathrm{KCl})}$ & 5.3 & $5.2 \pm 0.5$ & $5.3 \pm 0.6$ & $5.1 \pm 0.4$ \\
\hline $\mathrm{EC}_{\mathrm{e}}^{(1)}(\mathrm{dS} / \mathrm{m})$ & 0.058 & $0.100 \pm 0.040$ & $0.110 \pm 0.030$ & $0.060 \pm 0.030$ \\
\hline $\mathrm{H}^{+}\left(\mathrm{cmol}^{(+)} / \mathrm{kg}\right)$ & 0.60 & $0.59 \pm 0.31$ & $0.74 \pm 0.37$ & $0.44 \pm 0.26$ \\
\hline $\mathrm{P}(\mathrm{mg} / \mathrm{kg})$ & 153 & $114 \pm 61$ & $135 \pm 77$ & $153 \pm 89$ \\
\hline $\mathrm{Ca}^{2+}\left(\mathrm{cmol}^{(+)} / \mathrm{kg}\right)$ & 1.72 & $2.00 \pm 1.04$ & $2.01 \pm 0.99$ & $1.88 \pm 0.92$ \\
\hline $\mathrm{Mg}^{2+}\left(\mathrm{cmol}^{(+)} / \mathrm{kg}\right)$ & 0.80 & $0.84 \pm 0.41$ & $0.76 \pm 0.34$ & $0.80 \pm 0.30$ \\
\hline \multirow[t]{2}{*}{$\mathrm{C}(\%)$} & 0.74 & $0.71 \pm 0.26$ & $0.85 \pm 0.26$ & $0.74 \pm 0.26$ \\
\hline & \multicolumn{4}{|c|}{$90-180 \mathrm{~cm}$} \\
\hline $\mathrm{pH}_{(\mathrm{KCl})}$ & 4.7 & $4.6 \pm 0.4$ & $4.6 \pm 03$ & $4.6 \pm 0.3$ \\
\hline $\mathrm{EC}_{\mathrm{e}}(\mathrm{dS} / \mathrm{m})$ & 0.057 & $0.070 \pm 0.020$ & $0.100 \pm 0.040$ & $0.060 \pm 0.030$ \\
\hline $\mathrm{H}^{+}\left(\mathrm{cmol}^{(+)} / \mathrm{kg}\right)$ & 0.85 & $0.77 \pm 0.31$ & $0.97 \pm 0.29$ & $0.57 \pm 0.27$ \\
\hline $\mathrm{P}(\mathrm{mg} / \mathrm{kg})$ & 29 & $22 \pm 8$ & $26 \pm 9$ & $46 \pm 44$ \\
\hline $\mathrm{Ca}^{2+}\left(\mathrm{cmol}^{(+)} / \mathrm{kg}\right)$ & 0.30 & $0.36 \pm 0.31$ & $0.42 \pm 0.19$ & $0.50 \pm 0.50$ \\
\hline $\mathrm{Mg}^{2+}\left(\mathrm{cmol}^{(+)} / \mathrm{kg}\right)$ & 0.17 & $0.17 \pm 0.18$ & $0.15 \pm 0.09$ & $0.25 \pm 0.22$ \\
\hline $\mathrm{C}(\%)$ & 0.44 & $0.38 \pm 0.21$ & $0.49 \pm 0.16$ & $0.36 \pm 0.22$ \\
\hline
\end{tabular}

(1) Electrical conductivity of the saturated extract.

Soil $\mathrm{H}^{+}$did not respond to the different levels of dilution of the winery wastewater (data not shown). Baseline values for $\mathrm{H}^{+}$were $0.60 \mathrm{cmol}^{(+)} / \mathrm{kg}$ and $0.85 \mathrm{cmol}^{l^{(+)}} / \mathrm{kg}$ for the 0 to $90 \mathrm{~cm}$ and 90 to $180 \mathrm{~cm}$ soil layers respectively (Tables $1 \&$ 2). At the end of the trial in September 2013, $\mathrm{H}^{+}$in the 0 to $90 \mathrm{~cm}$ layer was similar to the baseline value, whereas $\mathrm{H}^{+}$in the 90 to $180 \mathrm{~cm}$ layer was slightly higher than the baseline value.

There were no clear trends in soil $\mathrm{EC}_{\mathrm{e}}$ that could be related to the different dilution levels compared to the river water control (data not shown). However, $\mathrm{EC}_{\mathrm{e}}$ was considerably higher after wastewater application compared to $\mathrm{EC}_{\mathrm{e}}$ at bud break (Table 1). This suggests an accumulation of salts during the grapevine-growing season - mainly due to irrigation with diluted winery wastewater, which contains salts (Laurenson et al., 2012). Although there were no consistent trends with regard to $\mathrm{EC}_{\mathrm{e}}$ in April 2011, $\mathrm{EC}_{\mathrm{e}}$ was more than double that in May 2010 (Table 1). This difference can be attributed to the heavy rainfall in May 2010, before the soil was sampled. In a laboratory study, soil $\mathrm{EC}_{(1: 5)}$ was not affected by irrigation with either mains water, municipal wastewater or winery wastewater regardless of soil type (Laurenson, 2010). Similarly, in another laboratory study, the soil EC of a loam and loamy sandy soil did not respond to winery wastewater irrigation (Kumar et al., 2006). However, soil EC was higher where woodlots were irrigated with winery wastewater compared to a control (Kumar et al., 2009). In the present study, in September 2013, i.e. at the end of the trial, $\mathrm{EC}_{\mathrm{e}}$ in the 0 to $90 \mathrm{~cm}$ soil layer was similar to the baseline values, whereas the $\mathrm{EC}_{\mathrm{e}}$ in the 90 to $180 \mathrm{~cm}$ layer was slightly higher than the baseline values (Table 1). Therefore, under the prevailing conditions, irrigation using diluted winery wastewater did not cause a long-term accumulation of salts in the soil. However, this does not rule out the possibility that winter rainfall could have leached salts beyond the measured depth. These results confirm the necessity for sufficient rainfall to reduce soil $\mathrm{EC}_{\mathrm{e}}$ where winery wastewater, which is known to contain high $\mathrm{Na}^{+}$and $\mathrm{K}^{+}$levels, is used for irrigation. Furthermore, the results emphasise the importance of irrigating only where the grapevine roots occur, i.e. within the root zone. In heavier textured soils, or in regions with lower winter rainfall, less effective leaching is more likely to result in greater salt accumulation, and consequently higher $\mathrm{EC}_{\mathrm{e}}$. During simulated rainfall cycles in a laboratory study, the drainage water EC was substantially higher than that of the input rainwater (Laurenson, 2010), which indicated that there was a net loss of salts during rainfall. These results emphasise the importance of regular rainfall cycles to reduce high soil $\mathrm{EC}_{\mathrm{e}}$, especially where municipal wastewater and winery wastewater, which contain high levels of salts, are used for irrigation.

\section{Phosphorus (Bray II)}

On average, the soil contained $114 \mathrm{mg} / \mathrm{kg}, 135 \mathrm{mg} / \mathrm{kg}$ and $153 \mathrm{mg} / \mathrm{kg}$ Bray II-P in the 0 to $90 \mathrm{~cm}$ layer in the vine rows after wastewater application in the 2010/2011, 2011/2012 and 2012/2013 seasons respectively (Table 2). These values are substantially higher than the norm of $20 \mathrm{mg} / \mathrm{kg} \mathrm{P}$ for 
sandy soils (i.e. $\leq 6 \%$ clay) based on Bray II extraction for soils with a $\mathrm{pH}_{(\mathrm{KCl})}$ of 5.5, as proposed by Conradie (1994). On average, the soil contained $22 \mathrm{mg} / \mathrm{kg}, 26 \mathrm{mg} / \mathrm{kg}$ and $46 \mathrm{mg} / \mathrm{kg}$ Bray II-P in the 90 to $180 \mathrm{~cm}$ soil layer after wastewater application in the 2010/2011, 2011/2012 and 2012/2013 seasons respectively (Table 2). These values were also higher than the norm for sandy soils. Since the grapevines would have absorbed only a small fraction of the available $\mathrm{P}$, the steady incline in the profile over time probably reflected the $\mathrm{P}$ applied via wastewater irrigation, as well as the $40.5 \mathrm{~kg}$ P applied for the cover crops on 30 March 2010 and 30 November 2011.

A perusal of the data revealed that soil Bray II-P in the 0 to $30 \mathrm{~cm}$ layer of the work rows increased linearly as the P applied via the diluted winery wastewater increased, particularly in the 2011/2012 and 2012/2013 seasons (Fig. 2). The $P$ in the 0 to $30 \mathrm{~cm}$ layer of the grapevine rows showed a similar trend (data not shown). However, this trend did not occur in the deeper soil layers. This suggests that the attenuation of $\mathrm{P}$ occurred only in the top $30 \mathrm{~cm}$ of this sandy, alluvial soil, which contained only c. $3.3 \%$ clay. There were no further relationships between soil Bray II-P in the sub-soil layers of both the work and vine rows and P applied via the diluted winery wastewater under the prevailing conditions (data not shown).

Baseline values for soil Bray II-P were $153 \mathrm{mg} / \mathrm{kg}$ and $29 \mathrm{mg} / \mathrm{kg}$ for the 0 to $90 \mathrm{~cm}$ and 90 to $180 \mathrm{~cm}$ soil layers respectively. Although soil Bray II-P in the 0 to $90 \mathrm{~cm}$ layer was substantially lower than the baseline values, $\mathrm{P}$ levels in the 90 to $180 \mathrm{~cm}$ layer were similar in September 2013 (Table 1). Since the amount of P applied via diluted winery wastewater appears to be generally low and would only sustain a grape yield of $c .10 \mathrm{t} / \mathrm{ha}$, the application of $\mathrm{P}$ fertilisers will probably still be necessary to ensure an adequate supply for the vines.

\section{Potassium (Bray II)}

Soil Bray II-K increased linearly with a decrease in wastewater dilution (Fig. 3). This was expected, since the additional $\mathrm{K}^{+}$applied via the diluted winery wastewater ranged, on average, from $6.6 \mathrm{~kg} / \mathrm{ha} /$ year for the river water control (T1) to $177.3 \mathrm{~kg} / \mathrm{ha} /$ year for the lowest level of dilution (T9). Furthermore, the additional $\mathrm{K}^{+}$applied via the diluted winery wastewater was applied in the postveraison period of the grapevine. Most of the $\mathrm{K}^{+}$uptake by the grapevine takes place prior to véraison, with almost no uptake from five weeks after harvest (Conradie, 1981). In particular, there was a good correlation between soil Bray II-K in the 0 to $30 \mathrm{~cm}$ layer of the work rows and the amounts of $\mathrm{K}^{+}$applied via the diluted wastewater (Fig. 3A). In the 2011/2012 and 2012/2013 seasons, soil Bray II-K in the 30 to $60 \mathrm{~cm}$ soil layer responded to the amount of $\mathrm{K}^{+}$applied via the diluted winery wastewater (Fig. 3B). With the exception of 2011/2012, there were no clear trends with regard to soil Bray II-K in the 60 to $90 \mathrm{~cm}$ as well as in the 90 to $120 \mathrm{~cm}$ soil layer and the amount of additional $\mathrm{K}^{+}$applied via the diluted winery wastewater (Figs. 3C \& D).

Similar results were observed in the grapevine rows (data not shown). It should be noted that the magnitude of the soil Bray II-K in the work and grapevine rows was similar, except that the soil Bray II-K in the 60 to $90 \mathrm{~cm}$ layer in the vine row responded better to wastewater dilution levels than in the work rows. Similar results with regard to an accumulation of soil $\mathrm{K}^{+}$in response to irrigation with winery wastewater have been reported previously (Mosse et al., 2012). Likewise, soil surface $\mathrm{K}^{+}$increased where winery wastewater was used for the irrigation of soil typical of the South Eastern Australia Riverine plains for three years (Quale et al., 2010). However, there were no changes in sub-soil $\mathrm{K}^{+}$due to slow mobility of $\mathrm{K}^{+}$in the soils, which contained c. $50 \%$ to $60 \%$ clay. Soil $\mathrm{K}^{+}$levels

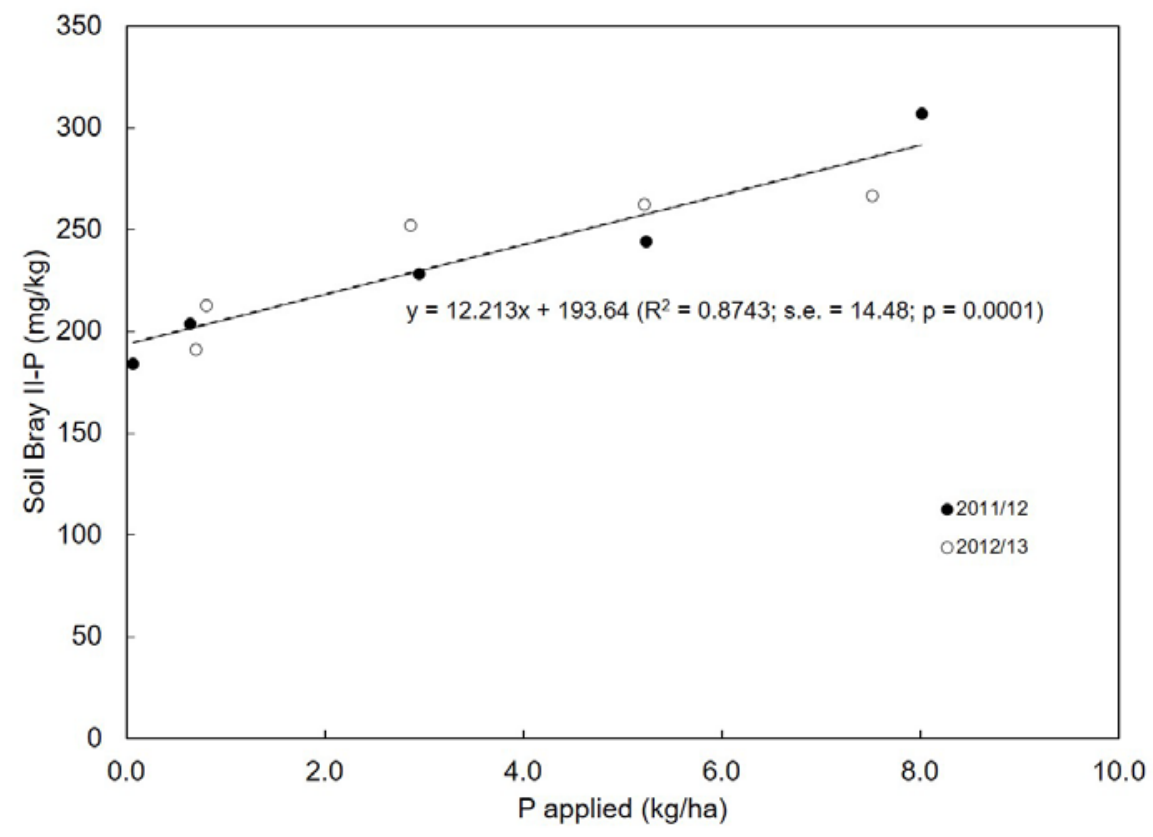

FIGURE 2

Effect of P applied via diluted winery wastewater on soil Bray II-P contents in the 0 to $30 \mathrm{~cm}$ layer in the work rows of a vineyard in a sandy soil near Rawsonville measured after wastewater application over two seasons. 

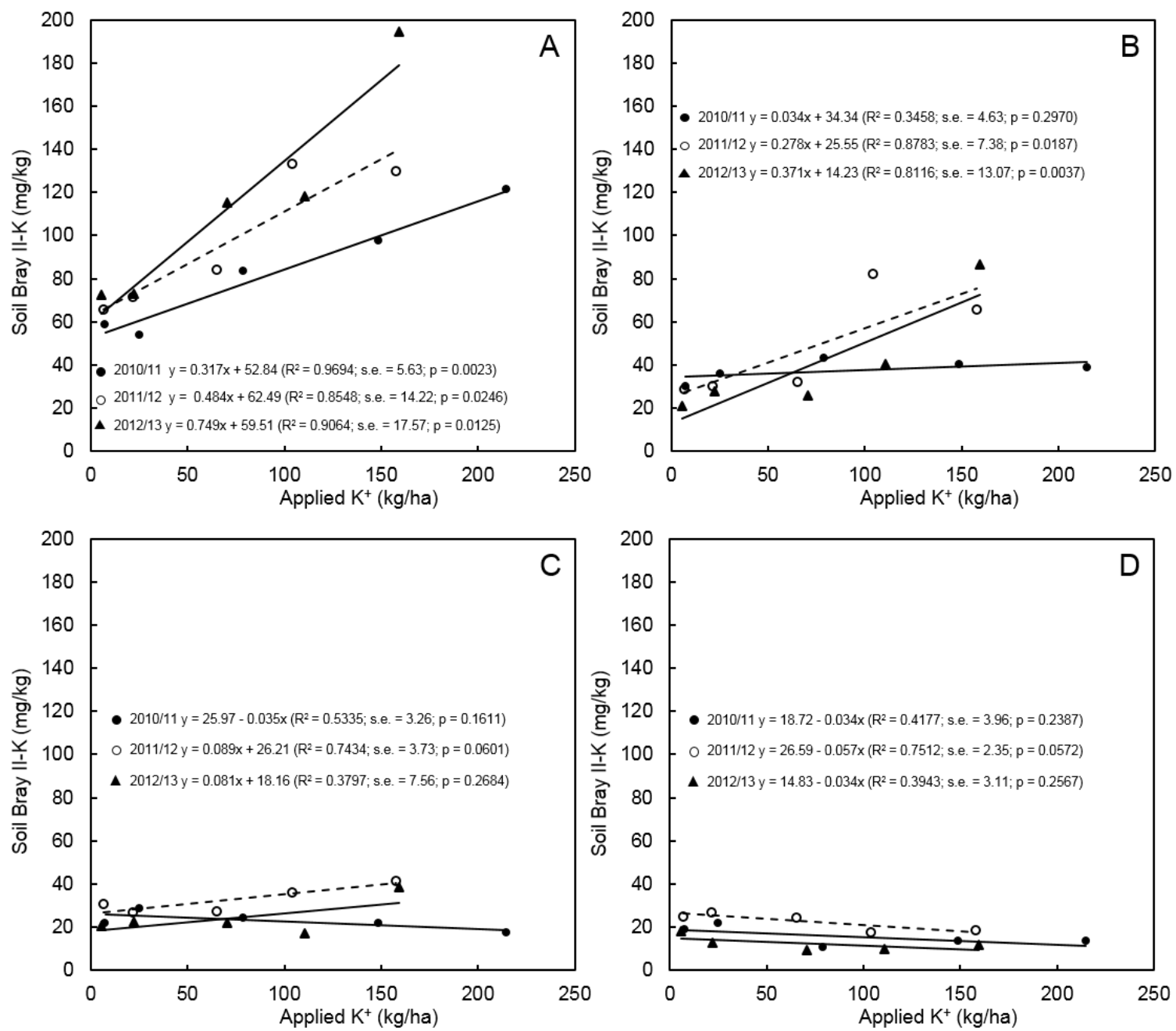

FIGURE 3

Effect of $\mathrm{K}^{+}$applied via diluted winery wastewater on soil Bray II-K contents in the (A) 0 to $30 \mathrm{~cm}$, (B) 30 to $60 \mathrm{~cm}$, (C) 60 to $90 \mathrm{~cm}$ and (D) 90 to $120 \mathrm{~cm}$ layers in the work rows of a vineyard in a sandy soil near Rawsonville measured after wastewater application over three seasons.

were also higher in vineyards that were irrigated with winery wastewater compared to control vineyard soils (Kumar et al., 2006). Furthermore, land application of wastewaters can increase the levels of soluble and exchangeable forms of $\mathrm{K}^{+}$more rapidly than conventional, inorganic fertilisers (Arienzo et al., 2009). In the only field study of its kind, in which simulated winery wastewater was used for vineyard irrigation, the addition of wine to the wastewater enhanced $\mathrm{K}^{+}$movement to the sub-soil. Although the fate of $\mathrm{K}^{+}$in soils and grapevines irrigated with winery wastewater has received limited attention (Laurenson et al., 2012), it is almost certain that high soil $\mathrm{K}^{+}$could lead to an increase in $\mathrm{K}^{+}$uptake by grapevines. This could have negative consequences on grapevine responses, such as musts with high $\mathrm{pH}$ and malate concentrations, and poor colour (Jackson \& Lombard, 1993; Mpelasoka et al., 2003; Kodur, 2011). However, the effect of soil $\mathrm{K}^{+}$on $\mathrm{K}^{+}$concentrations in the must is often negligible, unless excessive amounts are applied (Jackson \& Lombard, 1993).

When the winter rainfall was higher than the average of $300 \mathrm{~mm}$, i.e. in the $2011 / 2012$ and $2012 / 2013$ seasons, soil Bray II-K in the 0 to $30 \mathrm{~cm}$ soil layer at bud break was substantially lower than after wastewater application, particularly where winery wastewater was diluted to 2000 $\mathrm{mg} / \mathrm{L}$ COD and higher (data not shown). However, in 2010 and 2011, when there was much less winter rain, soil Bray II-K levels at bud break were similar to the levels after wastewater application. Furthermore, soil Bray II-K where winery wastewater was diluted to $2000 \mathrm{mg} / \mathrm{L}$ and higher was such that these treatments did not require any $\mathrm{K}$ fertilisation in the 2010/2011 season. With regard to deeper soil layers, there was less soil Bray II-K in the 30 to $60 \mathrm{~cm}$ and 60 to $90 \mathrm{~cm}$ soil layers at bud break during the wetter winters compared to after wastewater application. In contrast, there were no differences in soil Bray II-K at bud break in the drier winters compared to after wastewater application. However, it should be noted that, in the 2010/2011 season, there was, in fact, an accumulation of soil Bray II-K at bud break in the 30 to $60 \mathrm{~cm}$ and 60 to $90 \mathrm{~cm}$ soil layers. Although there is no explanation for this trend, it could be possible that the roots of the pearl millet interception crop absorbed $\mathrm{K}^{+}$ during wastewater application. Due to favourable, dry winter 
conditions, the roots of the interception crop mineralised, releasing $\mathrm{K}^{+}$. However, rainfall was too low to leach away the $\mathrm{K}^{+}$. This indicates insufficient leaching under the prevailing conditions. It should be noted that the quantification of the interception crop root mineralisation was beyond the scope of the study. With the exception of the 0 to $30 \mathrm{~cm}$ soil layer, it was evident that the heavy winter rainfall $(408 \mathrm{~mm})$ negated treatment differences with respect to soil Bray II-K at bud break in September 2013 (Fig. 4). This implies that the heavy winter rainfall probably leached $\mathrm{K}^{+}$from the soil profile, and this was substantiated by the mineral analysis of soil samples collected with a modified soil auger from deeper than $180 \mathrm{~cm}$. At the end of the trial in September 2013, soil Bray II-K levels in the 0 to $30 \mathrm{~cm}$ soil layer, where winery wastewater was diluted up to $2000 \mathrm{mg} / \mathrm{L} \mathrm{COD}$, were lower than the baseline value. In contrast, where winery wastewater was diluted to $3000 \mathrm{mg} / \mathrm{L}$, baseline levels were maintained in the 0 to $30 \mathrm{~cm}$ soil layer. Therefore, under the prevailing conditions, using winery wastewater diluted to $3000 \mathrm{mg} / \mathrm{L}$ COD was beneficial with regard to soil $\mathrm{K}^{+}$status.

\section{Extractable $\mathrm{K}^{+}, \mathrm{Ca}^{2+}, \mathrm{Mg}^{2+}$ and $\mathrm{Na}^{+}$}

Extractable $\mathrm{K}^{+}$exhibited similar trends to soil Bray II-K (data not shown) and will therefore not be discussed further. Since exchangeable $\mathrm{K}^{+}$was not determined in the laboratory, the ExPP rather than the EPP was calculated. For the Western Cape fruit industry, the recommended ratio of exchangeable $\mathrm{K}^{+}$to other cations is $3 \%$ to $4 \%$ (Conradie, 1994). The ExPP in the 0 to $30 \mathrm{~cm}$ soil layer could consistently be related to the amount of $\mathrm{K}^{+}$applied via the diluted winery wastewater (Fig. 5), and values were near the upper threshold of the recommended norm (Conradie, 1994). This implies that, if even more $\mathrm{K}^{+}$is applied to the soil via diluted winery wastewater, excessive $\mathrm{K}^{+}$could accumulate, causing even higher ExPP. Depending on the timing of the wastewater applications, there is the risk that the excessive $\mathrm{K}^{+}$could be applied when the grapevine is actively absorbing $\mathrm{K}^{+}$in the post-véraison period (Conradie, 1981). In the case of red wine production, this could cause high wine $\mathrm{pH}$ and wine instability (Mpelasoka et al., 2003; Kodur, 2011).

Soil $\mathrm{Ca}^{2+}$ and $\mathrm{Mg}^{2+}$ did not show any consistent trends with respect to the different levels of wastewater dilution (data not shown). The lack of response could be expected, since there were no substantial differences with regard to the amounts of additional $\mathrm{Ca}^{2+}$ and $\mathrm{Mg}^{2+}$ applied to the vineyard via the diluted winery wastewater. Similar results for soil $\mathrm{Ca}^{2+}$ were also reported where winery wastewater was used for irrigation (Quale et al., 2010). However, in that particular study, soil $\mathrm{Mg}^{2+}$ tended to decrease. In the present study, baseline values for $\mathrm{Ca}^{2+}$ were $1.72 \mathrm{cmol}^{(+)} / \mathrm{kg}$ and $0.30 \mathrm{cmol}^{(+)} / \mathrm{kg}$ for the 0 to $90 \mathrm{~cm}$ and 90 to $180 \mathrm{~cm}$ soil layers respectively (Tables 1 and 2). Baseline values for $\mathrm{Mg}^{2+}$ were $0.80 \mathrm{cmol}^{(+)} / \mathrm{kg}$ and $0.17 \mathrm{cmol}^{(+)} / \mathrm{kg}$ for the 0 to $90 \mathrm{~cm}$ and 90 to $180 \mathrm{~cm}$ soil layers, respectively. At bud break in September 2013, soil $\mathrm{Ca}^{2+}$ and $\mathrm{Mg}^{2+}$ were similar to these baseline values. This confirms that the irrigation of vineyards with diluted winery wastewater is unlikely to be beneficial with regard to an increased $\mathrm{Ca}^{2+}$ and $\mathrm{Mg}^{2+}$ supply for grapevines. In addition, if applied in such small amounts, these elements will not be able to counter the negative effects of high levels of $\mathrm{Na}^{+}$applied via diluted winery wastewater.

Work row soil $\mathrm{Na}^{+}$in the 0 to $30 \mathrm{~cm}$ as well as the 60 to $90 \mathrm{~cm}$ soil layers increased linearly with a decrease in wastewater dilution, i.e. with an increase in the COD level of the irrigation water (Figs. 6A \& 6C). This was expected, since the additional $\mathrm{Na}^{+}$applied via the diluted winery wastewater ranged, on average, from $37.6 \mathrm{~kg} / \mathrm{ha} /$ year for the river water control to $92.6 \mathrm{~kg} / \mathrm{ha} /$ year for the lowest level

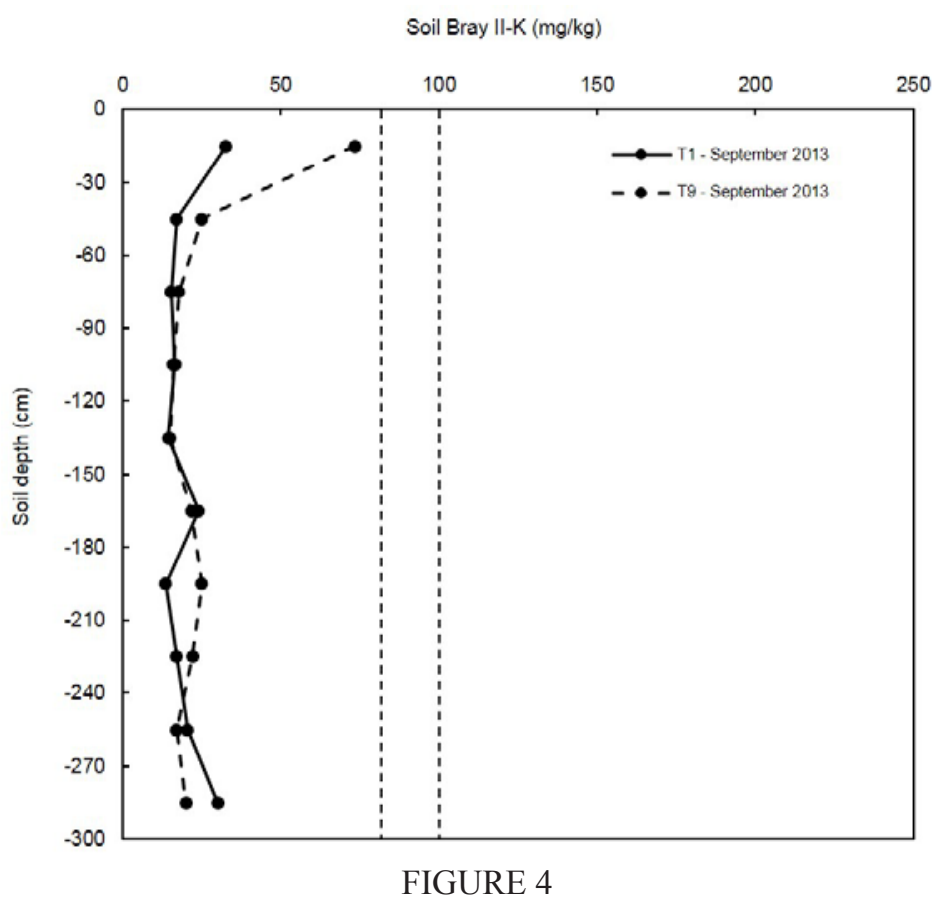

Soil Bray II-K contents over 3 m depth measured near Rawsonville in September 2013. Dashed vertical lines indicate the optimal norm for Bray II-K in alluvial soils of the Breede River Valley (Conradie, 1994). 
of dilution. It should be noted that the Holsloot River had a relatively high $\mathrm{Na}^{+}$(Howell et al., 2015). At this stage, there is no explanation for why soil $\mathrm{Na}^{+}$levels in the 30 to $60 \mathrm{~cm}$ soil layer did not respond consistently to the different levels of dilution compared to the 0 to $30 \mathrm{~cm}$ as well as the 60 to $90 \mathrm{~cm}$ soil layers. Several studies have also reported an increase in soil $\mathrm{Na}^{+}$in response to irrigation with wastewater (Mosse et al., 2012). In a field study in which grapevines were irrigated with simulated winery wastewater, soil $\mathrm{Na}^{+}$ levels increased in the 0 to $20 \mathrm{~cm}$ as well as the 20 to $40 \mathrm{~cm}$ soil layers (Mosse et al., 2013). At bud break, soil $\mathrm{Na}^{+}$in the 0 to $30 \mathrm{~cm}$ soil layer was consistently lower than after wastewater application (data not shown). Likewise, when winters were wetter, the soil $\mathrm{Na}^{+}$in the 30 to $60 \mathrm{~cm}$ and 60 to $90 \mathrm{~cm}$ soil layers were lower at bud break compared to after wastewater application. However, when winters were drier, i.e. in 2010 and 2011, these trends were not consistent in deeper soil layers. Therefore, when winter rainfall was higher, there was sufficient leaching to remove the $\mathrm{Na}^{+}$from the root zone. However, the redistribution and accumulation of $\mathrm{Na}^{+}$in the root zone during the drier winters is a cause for concern. After the heavy rainfall in the winter of 2013, the $\mathrm{Na}^{+}$levels of T1, T3 and T5 were lower than the baseline values (Fig. 7). Soil $\mathrm{Na}^{+}$for the lowest level of dilution at the end of the trial, i.e. winery wastewater diluted to $3000 \mathrm{mg} / \mathrm{L}$ COD, was not substantially more than that of the river water control. Therefore, under field conditions, using diluted winery wastewater for vineyard irrigation did not have any long-term negative consequences on soil $\mathrm{Na}^{+}$. However, for a heavier textured soil or where rainfall is substantially less than that of the Breede River Valley, the accumulation of $\mathrm{Na}^{+}$ in the soil could be more prominent. In general, the ExSP did not exceed the critical threshold of $15 \%$ for sustainable agricultural use (Laker, 2004; Seilsepour et al., 2009).

\section{Organic C}

There were no consistent trends with regard to soil organic $\mathrm{C}$ that could be related to the level of dilution of the winery wastewater (data not shown). This indicates that the organic $\mathrm{C}$ content of the diluted wastewaters was still too low to have a positive effect on soil fertility. It is also possible that organic material in the diluted wastewaters, which could have led to an accumulation of organic soil $\mathrm{C}$, decomposed when the soil was aerated between irrigations. In contrast, Kumar et al. (2009) report that the higher organic C content of winery wastewater results in an increased total organic $\mathrm{C}$ content in soils irrigated with such wastewater. In the present study, baseline values for $\mathrm{C}$ were $0.74 \%$ and $0.44 \%$ for the 0 to $90 \mathrm{~cm}$ and 90 to $180 \mathrm{~cm}$ soil layers, respectively. At the end of the trial, in September 2013, soil C was $0.67 \%$ and $0.41 \%$ for the 0 to $90 \mathrm{~cm}$ and 90 to $180 \mathrm{~cm}$ soil layers respectively (Table 1). These levels were similar to baseline values.

\section{CONCLUSIONS}

Where diluted winery wastewater was used for the irrigation of a vineyard in a sandy, alluvial soil, there was a consistent increase in soil Bray II-K after wastewater application. The increase in soil Bray II-K was linearly related to the additional amounts of $\mathrm{K}^{+}$applied via the diluted winery wastewater. Soil $\mathrm{K}^{+}$increases could have a negative impact on wine colour stability, should it be taken up by the grapevine in sufficient quantities, particularly if soil $\mathrm{K}^{+}$accumulates to such an extent that it is luxuriously absorbed by grapevines, which was not the case in the current experiment. Soil $\mathrm{Ca}^{2+}$ and $\mathrm{Mg}^{2+}$ did not respond to levels of dilution of the winery wastewater. This was probably due to their low levels in the diluted winery wastewater. Soil $\mathrm{Na}^{+}$also increased linearly as the level of wastewater dilution decreased, particularly

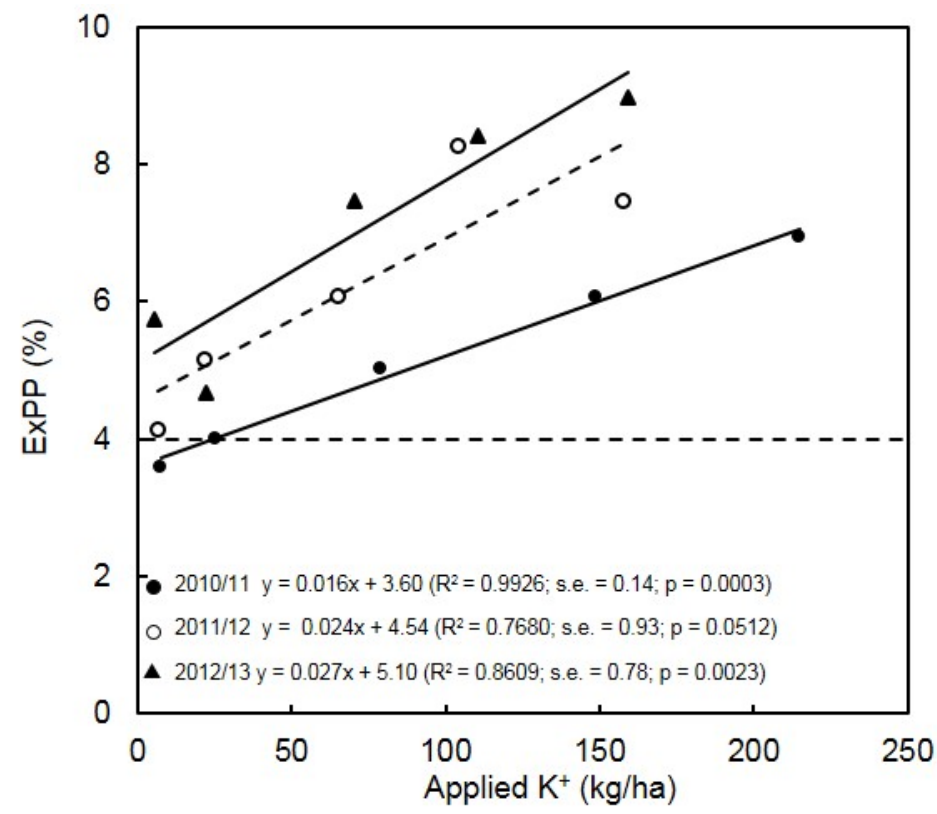

FIGURE 5

Effect of $\mathrm{K}^{+}$applied via diluted winery wastewater on soil extractable $\mathrm{K}^{+}$percentage (ExPP) in the 0 to $30 \mathrm{~cm}$ layer in the work rows of a vineyard in a sandy soil near Rawsonville measured after wastewater application over three seasons. Dashed horizontal line indicates the critical ExPP threshold for grapevines (Conradie, 1994). 

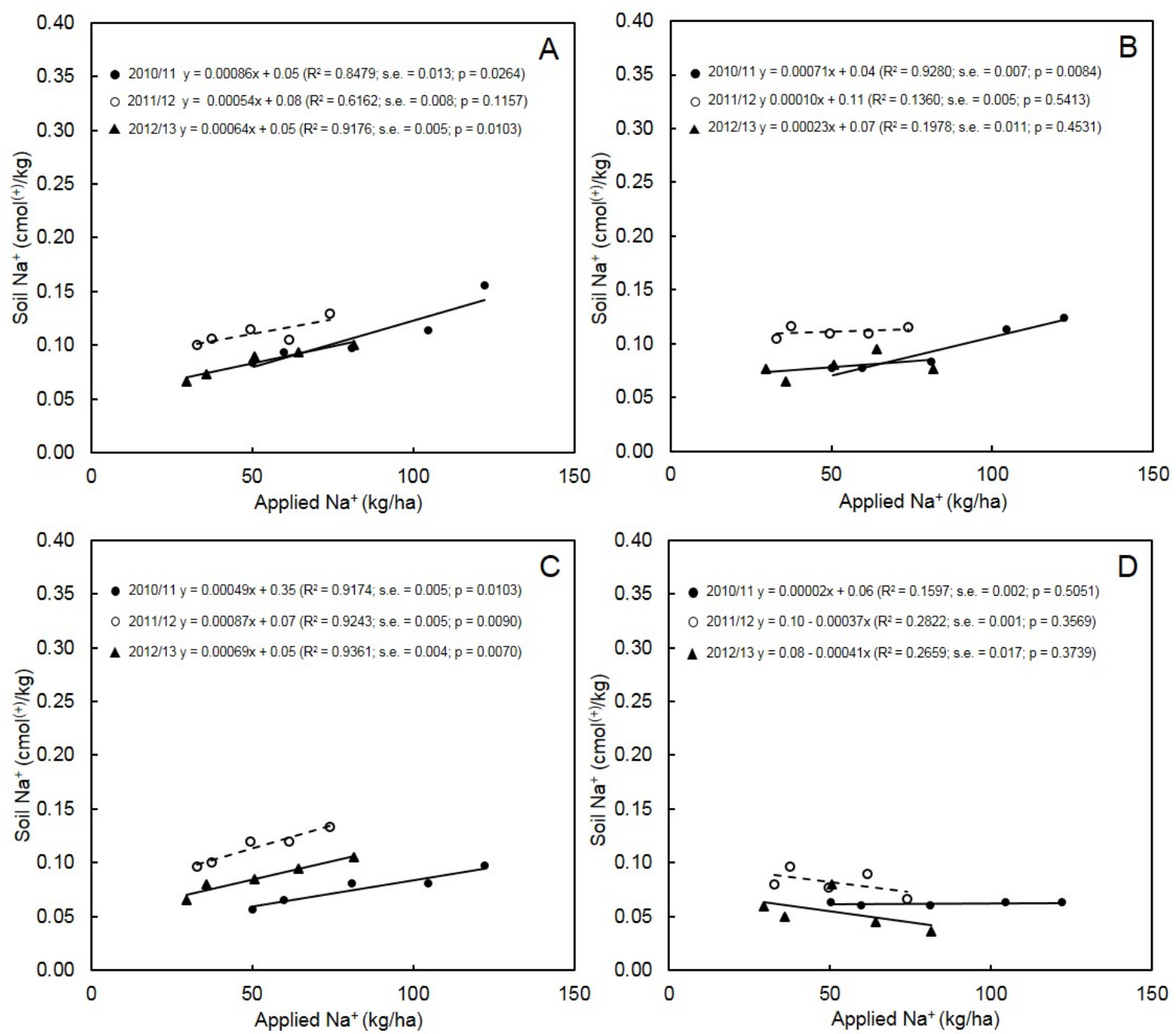

FIGURE 6

Effect of $\mathrm{Na}^{+}$applied via diluted winery wastewater on soil $\mathrm{Na}^{+}$contents in the (A) 0 to $30 \mathrm{~cm}$, (B) 30 to $60 \mathrm{~cm}$, (C) 60 to 90 $\mathrm{cm}$ and (D) 90 to $120 \mathrm{~cm}$ layers in the work rows of a vineyard in a sandy soil near Rawsonville measured after wastewater application over three seasons.

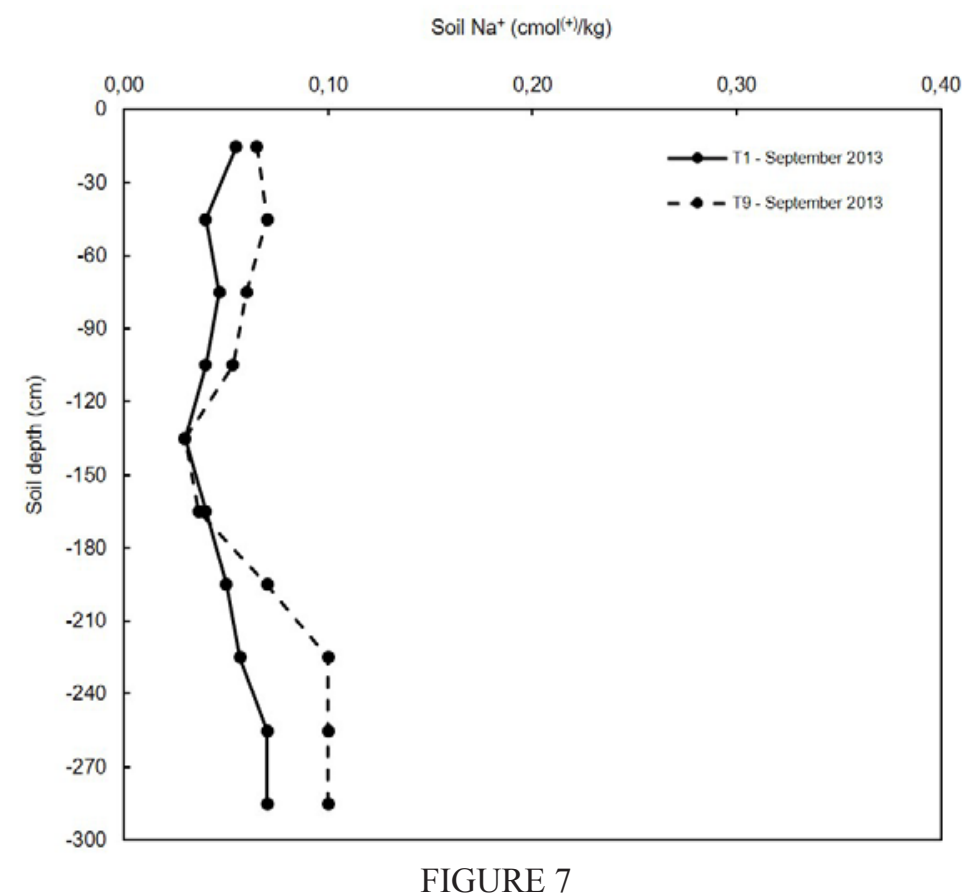

Soil $\mathrm{Na}^{+}$contents over $3 \mathrm{~m}$ depth measured near Rawsonville in September 2013. 
in the topsoil. In heavier textured soils, or in regions with lower winter rainfall, soil $\mathrm{K}^{+}$and $\mathrm{Na}^{+}$could accumulate to levels at which they could impact negatively on soil physical conditions or grapevine growth and yield. In addition, natural water resources could be polluted with these elements during the winter. Changes in cation ratios due to the accumulation of $\mathrm{K}^{+}$and $\mathrm{Na}^{+}$. with no consequent increase in $\mathrm{Ca}^{2+}$ and $\mathrm{Mg}^{2+}$, could be detrimental in terms of soil physical properties. It should be noted that the results represent a specific in-field situation, i.e. in the presence of rainfall and crops. The study only addressed the suitability of using winery wastewater for the irrigation of grapevines in a sandy soil under one set of climatic conditions. Future research should focus on the use of winery wastewater for the irrigation of different soil types in different climatic regions.

\section{LITERATURE CITED}

Abrol, I.P., Yadav, J.S.P. \& Massoud, F.I., 1988. Salt affected soils and their management. FAO Soils Bulletin No. 39, FAO, Rome.

Arienzo, M., Christen, E.W., Quayle, W. \& Kumar, A., 2009. A review of the fate of potassium in the soil-plant system after land application of wastewaters. J. Hazard. Mater. 164, 415-422.

Barbera, A.C., Maucieri, C., Cavallaro, V., Ioppolo, A. \& Spagna, G., 2013. Effects of spreading olive mill wastewater on soil properties and crops, a review. Agr. Water Manage. 119, 43-53.

Blum, J., Herpin, U., Melfi, A.J. \& Montes, C.R., 2012. Soil properties in a sugarcane plantation after the application of treated sewage effluent and phosphogypsum in Brazil. Agr. Water Manage. 115, 203-216.

Booysen, J.H., Steenkamp, J. \& Archer, E., 1992. Names of vertical trellis systems (with abbreviations). Wynboer, September, 15.

Conradie, W.J., 1981. Seasonal uptake of nutrients by Chenin blanc in sand culture: II. Phosphorus, potassium, calcium and magnesium. S. Afr. J. Enol. Vitic. 2, 7-13

Conradie, W.J., 1994. Vineyard fertilisation. Proceedings of Workshop on Vineyard Fertilization. Nietvoorbij, 30 September. ARC InfruitecNietvoorbij, Private Bag X5026, 7599 Stellenbosch, South Africa.

Department of Water Affairs, 2013. Revision of general authorisations in terms of Section 39 of the National Water Act, 1998 (Act No. 36 of 1998), No. 665. Government Gazette No. 36820, 6 September 2013. Department of Water Affairs, Pretoria, South Africa.

Di Bene, C., Pellegrino, E., Debolini, M., Silvestri, N. \& Bonari, E., 2013. Short- and long-term effects of olive mill wastewater land spreading on soil chemical and biological properties. Soil Biol. Biochem. 56, 21-30.

Duan, R., Sheppard, C.D. \& Fedler, C.B., 2010. Short-term effects of wastewater application on soil chemical properties. Water Air Soil Poll. $211,165-176$.

Fourie, J.C., Theron, H. \& Ochse, C.H., 2015. Effect of irrigation with diluted winery wastewater on the performance of two grass cover crops in vineyards. S. Afr. J. Enol. Vitic. 36, 210-222.

Howell, C.L. \& Myburgh, P.A., 2018. Management of winery wastewater by re-using it for crop irrigation - A review. S. Afr. J. Enol. Vitic. 39, 116131.

Howell, C.L., Myburgh, P.A., Lategan, E.L \& Hoffman, J.E., 2015. An assessment of winery wastewater diluted for irrigation of grapevines in the Breede River Valley with respect to water quality and nutrient load. S. Afr. J. Enol. Vitic. 36, 413-425.
Hulugalle, N.R., Weaver, T.B., Ghadiri, H. \& Hicks, A., 2006. Changes in soil properties of an eastern Australian vertisol irrigated with treated sewage effluent following gypsum application. Land Degrad. Develop. 17, 527-540.

Jackson, D.I. \& Lombard, P.B., 1993. Environmental and management practices affecting grape composition and wine quality. Am. J. Enol. Vitic. $44,409-430$

Kodur, S., 2011. Effect of juice $\mathrm{pH}$ and potassium on juice and wine quality, and regulation of potassium in grapevines through rootstocks (Vitis): A short review. Vitis 50, 1-6.

Kumar, A., Arienzo, M., Quale, W., Christen, E., Grocke, S., Fattore, A., Doan, H., Gonzago, D., Zandonna, R., Bartrop, K., Smith, L., Correl, R. \& Kookana, R., 2009. Developing a systematic approach to winery wastewater management. Report CSL05/02. Grape and Wine Research Development Corporation/CSIRO Land and Water Science, Adelaide, Australia.

Kumar, A., Rengasamy, P., Smith, L., Doan, H., Gonzago, D., Gregg, A., Lath, S., Oats, D. \& Correl, R., 2014. Sustainable recycled winery water irrigation based on treatment fit for purpose approach. Report CSL1002. Grape and Wine Research Development Corporation/CSIRO Land and Water Science, Adelaide, Australia.

Kumar, A., Saison, C., Grocke, S., Doan, H., Correl, R. \& Kookana, R., 2006. Impact of winery wastewater on ecosystem health - An introductory assessment. Report CSL02/03. Grape and Wine Research Development Corporation/CSIRO Land and Water Science, Adelaide, Australia.

Lado, M., Bar-Tal, A., Azenkot, A., Assouline, S., Ravina, I., Erner, Y., Fine, P., Dasberg, S. \& Ben-Hur, M., 2011. Changes in chemical properties of semiarid soils under long-term secondary treated wastewater irrigation. Soil Sci. Soc. Am. J. 76, 1358-1369.

Laker, M.C., 2004. Advances in soil erosion, soil conservation, land suitability evaluation and land use planning research in South Africa, 19782003. S.A. J. Plant Soil 21, 345-366.

Laurenson, S., 2010. The influence of recycled water irrigation on cation dynamics in relation to the structural stability of vineyard soils. Dissertation, University of South Australia, G.P.O. Box 2471, Adelaide 5001, Australia.

Laurenson, S., Bolan, N.S. \& McCarthy, M., 2011. Effects of $\mathrm{K}^{+}$on Na-Ca exchange and the SAR-ESP relationship. Soil Res. 49, 538-546.

Laurenson, S., Bolan, N.S., Smith, E. \& McCarthy, M., 2012. Review: Use of recycled wastewater for irrigating grapevines. Aust. J. Grape Wine Res. $18,1-10$.

Le Roux, E.G., 1974. A climate classification for the South Western Cape viticultural areas (in Afrikaans). Thesis, Stellenbosch University, Private Bag X1, 7602 Matieland (Stellenbosch), South Africa.

Moraetis, D., Stamati, F.E., Nikolaidis, N.P. \& Kalogerakis, N., 2011. Olive mill wastewater irrigation on maize: Impacts on soil and groundwater. Agr. Water Manage. 98, 1125-1132.

Mosse, K.P.M., Lee, J., Leachman, B.T., Parikh, S.J., Cavagnaro, T.R., Patti, A.F. \& Steenworth, K.L., 2013. Irrigation of an established vineyard with winery cleaning agent solution (simulated winery wastewater): Vine growth, berry quality, and soil chemistry. Agr. Water Manage. 123, 93-102.

Mosse, K.P.M., Patti, A.F., Christen, E.W. \& Cavagnaro, T.R., 2011. Review: Winery wastewater quality and treatment options in Australia. Aust. J. Grape Wine Res. 17, 111-122.

Mosse, K.P.M., Patti, A.F., Smernik, R.J., Christen, E.W. \& Cavagnaro, T.R., 2012. Physicochemical and microbiological effects of long-term and short-term winery wastewater application to soils. J. Hazard. Mater. 201202, 219-228.

Mpelasoka, B.S., Schachtman, D.P., Treeby, M.T. \& Thomas, M.R., 2003. A review of potassium nutrition in grapevines with special emphasis on berry accumulation. Aust. J. Grape Wine Res. 9, 154-168. 
Mulidzi, R., Laker, G. \& Wooldridge, J., 2009. Composition of effluents from wineries in the Western and Northern Cape provinces (Part 2): Impacts on soil and the environment. Wynboer Technical Yearbook 2009/10, 62-68.

Myburgh, P.A., Lategan, E.L. \& Howell, C.L., 2015. Infrastructure for irrigation of grapevines with diluted winery wastewater in a field experiment. Water SA 41, 643-647.

Netzer, Y., Shenker, M. \& Schwartz, A., 2014. Effects of irrigation using treated wastewater on table grape vineyards: Dynamics of sodium accumulation in soil and plant. Irrig. Sci. 32, 283-294.

Peel, M.C., Finlayson, B.L. \& McMahon T.A., 2007. Updated world map of the Koppen-Geiger climate classification. Hydrol. Earth Syst. Sci. 11, 1633-1644.

Petrie, P.R., Cooley, N.M. \& Clingeleffer, P.R., 2004. The effect of postvéraison water deficit on yield components and maturation of irrigated Shiraz (Vitis vinifera L.) in the current and following season. Aust. J. Grape Wine Res. 10, 203-215.

Quale, W.C., Jayawardane, N. \& Arienzo, M., 2010. Impacts of winery wastewater irrigation on soil and groundwater at a winery land application site. Proc. $19^{\text {th }}$ World Congress of Soil Science: Soil solutions for a changing world, 1-6 August 2010, Brisbane, Australia.

Rana, L., Dhankhar, R. \& Chikara, S., 2010. Soil characteristics affected by long term application of sewage wastewater. Int. J. Environ. Res. 4, 513518

Richards, L.A., 1954. Diagnosis and improvement of saline and alkaline soils. Agriculture Handbook No. 60, US Dept. Agric, US Government Printing Office, Washington DC.

Rukshana, F., Butterly, C.R., Baldock, J.A. \& Tang, C., 2011. Model organic compounds differ in their effects on $\mathrm{pH}$ changes of two soils differing in initial pH. Biol. Fertil. Soils 47, 51-62.
Saayman, D., 1981. Climate, soil and vineyard regions (in Afrikaans). In: Burger, J. \& Deist, J. (eds). Wingerdbou in Suid-Afrika. ARC InfruitecNietvoorbij, Private Bag X5026, Stellenbosch 7599, South Africa.

Seilsepour, M., Rashidi, M. \& Khabbaz, B.G., 2009. Prediction of soil exchangeable sodium percentage based on soil sodium adsorption ratio. Am.-Eurasian J. Agric. Environ. Sci. 5, 1-4.

Smiles, D.E. \& Smith, C.J., 2004. A survey of the cation content of piggery effluents and some consequences of their use to irrigate soils. Aust. J. Soil Res. 42, 231-246.

Soil Classification Working Group, 1991. Soil classification - A taxonomic system for South Africa. Memoirs on natural resources of South Africa no. 15. Dept. Agric. Developm., Private Bag X116, 0001 Pretoria, South Africa.

The Non-Affiliated Soil Analyses Work Committee, 1990. Handbook of standard soil testing methods for advisory purposes. Soil Sci. Soc. S.A., P.O. Box 30030, Sunnyside, Pretoria.

Van Schoor, L.H., 2005. Guidelines for the management of wastewater and solid waste at existing wineries. Winetech. Available at: http://www.ipw. co.za/content/guidelines/WastewaterApril05English.pdf

Van Zyl, J.L. \& Weber, H.W., 1981. The effect of various supplementary irrigation treatments on plant and soil moisture relationships in a vineyard (Vitis vinifera var. Chenin blanc). S. Afr. J. Enol. Vitic. 2, 83-99.

Walker, C.W. \& Lin, H., 2008. Soil property changes after four decades of wastewater irrigation: A landscape perspective. Catena 73, 63-74.

Walkley, A. \& Black, I.A., 1934. An examination of Degtjareff method for determining soil organic matter and a proposed modification of the chromic acid titration method. Soil Sci. 37, 29-37.

Winkler, A.J., 1962. General viticulture. University of California Press, Los Angeles. 